\title{
Chrzest i dedykacja - między sacrum a profanum
}

\author{
Baptism and dedication - \\ between the sacred and the profane
}

\author{
Gabriela Olchowa \\ Filozofická faculta, Univerzita Mateja Bela v Banskej Bystrici, \\ Tajovského 55, 97401 Banská Bystrica, Slovenská republika; \\ e-mail: Gabriela.Olchowa@umb.sk
}

\begin{abstract}
Abstrakt
Przedmiotem artykułu jest chrzest i nadanie imienia w kontekście dualizmu sacrum - profanum. Autorka ukazuje walkę władz komunistycznych z Kościołem, spychanie religii na margines i laicyzowanie Polaków i Słowaków poprzez działania o charakterze administracyjnym. Zarówno w Polsce, jak i na Słowacji miały one na celu odciągnięcie wiernych od uroczystości religijnych i przyjmowania sakramentów świętych poprzez przejęcie przez administrację państwową organizacji świeckich obrzędów. W artykule został przedstawiony scenariusz i oprawa dedykacji (uvitanie detí do života) w czasach komunistycznych. Następnie autorka prezentuje stan obecny w obu krajach. Zwraca uwagę, że po upadku komunizmu współcześnie w polskich urzędach nie organizuje się tej uroczystości w przeciwieństwie do Słowacji, gdzie przetrwała i funkcjonuje w społeczeństwie słowackim. W tekście został zawarty opis współczesnej ceremonii uvitanie detí do života, która niewiele różni się od tej z czasów komunistycznych. Podkreśla się, że z kolei w Polsce pojawiają się uroczystości alternatywne dla chrztu, wzorowane na zachodnich zwyczajach - naming party, które budzą zainteresowanie pewnych grup.
\end{abstract}

Słowa kluczowe: sacrum; profanum; Słowacja; dedykacja; chrzest.

\begin{abstract}
The article presents baptism and dedication in the context of the duality of the sacred-profane. The author shows the struggle between the Communist authorities with the Church, pushing religion to the margins and secularizing Poles and Slovaks through administrative actions. Both in Poland and Slovakia they had to divert the faithful from religious ceremonies and reception of the sacraments, by taking over the administrative organization of secular ceremonies. The article presents the script and setting of the dedication Uvitanie deti to života in the communist era. Then the author presents the current state in both countries. She notes that after the fall of communism, today in Polish offices this event is not organized, contrary to Slovakia, where it survived and operates in Slovak society. The text includes a description of the contemporary Uvitanie deti to života ceremony, which is not that different to those of communist times. It emphasizes that, in turn, in Poland there are alternative baptism ceremonies, modeled on Western habits - naming party, which draws the interest of certain groups.
\end{abstract}

Keywords: the sacred; the profane; Slovakia; dedication; baptism. 
Po II wojnie światowej w Polsce i Czechosłowacji władza komunistyczna prześladowała Kościół. Starała się zneutralizować duchowieństwo, rugować je z życia społecznego, utrudniając mu działalność nawet w sferze charytatywnej. Zaczęło się spychanie religii na margines i laicyzowanie społeczeństwa tych krajów.

W monografii Komuniści i Kościół w Polsce (1945-1989) autorzy Antoni Dudek i Ryszard Gryz podają, że „Kontrakcja władz, mająca na celu ograniczenie wpływów Kościoła została podjęta na dwóch płaszczyznach: instytucjonalnej i propagandowej. Stopniowo nasilały się też działania o charakterze administracyjnym” (2003: 125). Historycy stwierdzają: „przez cały okres gomułkowski polityka wyznaniowa władz nakierowana była na ograniczanie wpływów Kościoła metodami administracyjnymi” (Dudek, Gryz 2003: 125). Zarówno w Polsce, jak i na Słowacji miała ona na celu odciągnięcie wiernych od uroczystości religijnych i przyjmowania sakramentów świętych poprzez przejęcie przez administrację państwową organizacji świeckich obrzędów. Próbkę tego można było zobaczyć w Polsce w 1966 roku, kiedy komuniści, by umniejszyć znaczenie rocznicy milenijnej, zorganizowali konkurencyjne uroczystości państwowe, które oczywiście propagowano przez środki masowego przekazu.

Punktem wyjścia do opracowania nowej koncepcji ,zobojętnienia religijnego społeczeństwa" (Dudek, Gryz 2003: 125) były wzory nowej obrzędowości, dzięki której starano się zlaicyzować życie Polaków i Słowaków. Był to typowy przykład laicyzacji sterowanej, oznaczającej ,,proces zaplanowany, odgórny, zamierzony politycznie, często związany z ideologią laicyzmu, czyli programem odrzucenia wszelkiej rzeczywistości transcendentalnej jako szkodliwej dla rozwoju ludzkości” (Przybylska 2014: 29).

W niniejszym artykule zostanie przedstawiona dedykacja (nadanie imienia) w kontekście dualizmu sacrum - profanum. Termin święty w teologii zarezerwowany jest dla Boga oraz tego wszystkiego, co dotyczy relacji człowieka z Bogiem, a więc sakramentów i innych czynności liturgicznych (Kłoczowski 2003: 24). Te przeciwstawne siły - sacrum i profanum, następująco przedstawił Roger Caillois:

Z jednej strony owa zaraźliwość sacrum sprawia, że wylewa się ona natychmiast na świat świecki, pociągając ze sobą niebezpieczeństwo, iż go zniszczy i samo bezowocnie zginie. $Z$ drugiej strony profanum odczuwa potrzebę sacrum, zawsze chciwie pragnie nim zawładnąć, ryzykując jego deprecjację lub własne unicestwienie (1995: 24).

Przyjście na świat dziecka, zawarcie związku małżeńskiego i zgon, a także związane z nimi chrzest, ślub i pogrzeb stanowią obrzędy przejścia, niezwykle ważne wydarzenia w życiu człowieka, dlatego też władze komunistyczne w Czechosłowacji stworzyły świecką obrzędowość, która miała wyprzeć religię z prywatnego życia obywateli „bloku sowieckiego”. I tak, między innymi chrzest kościelny komuniści próbowali zastąpić obrzędem uroczystego nadania imienia - dedykacją, a na Słowacji vitaniem občanov. W obu krajach działaczy partii 
i pracowników służby mundurowej obowiązywał zakaz udziału w ceremoniach religijnych. Świadczą o tym zalecenia Centralnej Komisji Kontroli Partyjnej „Musimy zdecydowanie przeciwdziałać klerykalizmowi i religianctwu w partii” (Osęka 2016). Komunista, który chrzcił dziecko, przystępował do spowiedzi, brał ślub kościelny itp., dopuszczał się „,zdrady ideologicznej” (Marek, Bortlik-Dźwierzyńska 2015).

Z Polskiej Kroniki Filmowej można dowiedzieć się, że „pierwszy tzw. chrzest cywilny w Warszawie odbył się w 1968 roku w Urzędzie Stanu Cywilnego Praga Północ z udziałem dzieci milicjantów" (www 3). Uroczystości tego typu miały przeważnie stały przebieg. Do rodziców nowo narodzonych dzieci wysyłano zaproszenia na państwowy chrzest. Jak opisuje Wojciech Świątkiewicz:

zamiast księdza był urzędnik, najczęściej kierownik urzędu stanu cywilnego, a zamiast rodziców chrzestnych - tzw. honorowi opiekunowie dziecka. W programach ateizacji propagowanych przez lektorów szkolenia partyjnego zalecano, aby tego typu „,uroczystość" - dla podniesienia jej rangi - odbywała się w salach, w których zawierane są cywilne małżeństwa. Matce i ojcu przynoszącym swoje dziecko powinni towarzyszyć członkowie związków zawodowych, Ligi Polskich Kobiet, a także przedstawiciele rady narodowej. Oczywiście w przypadku milicjantów i esbeków oraz wojskowych powinni być ich przełożeni, a w przypadku funkcjonariuszy partyjnych - pierwsi sekretarze odpowiedniego szczebla komitetu (2016).

Odgórnie zaplanowano także oprawę muzyczną: „zestaw utworów przygotował Departament Społeczno-Administracyjny MSW. Na przykład, na rozpoczęcie Kołysanka Brahmsa, na zakończenie - Polonez z Hrabiny Moniuszki" (Semik 2015). Szczegółowy scenariusz przedstawił Świątkiewicz:

Kierownik USC wygłaszał przemówienie, w którym wyrażał radość z „doniosłego aktu wprowadzenia dziecka w poczet członków społeczeństwa”. Zwracał się do rodziców, aby podali imię (imiona) dziecka, i przyjmował od nich przyrzeczenie: „Przyrzekamy uroczyście dołożyć wszelkich starań w wychowanie naszego syna/córki na uczciwego (uczciwą) obywatela (obywatelkę) Polski”. Honorowi opiekunowie zaś zobowiązywali się do „zaszczytnego obowiązku otoczenia dziecka opieką i moralnym poparciem, gdy zajdzie tego potrzeba". Zarówno ojciec i matka, jak i honorowi opiekunowie składali w dokumentach swoje podpisy. Rodzice otrzymywali tzw. Księgę Pamiątkową Uroczystego Nadania Imion (pisownia oryginalna) oraz list gratulacyjny od kierownika USC. W tym ostatnim pisano: „Rodzice przyrzekają, że wychowają swoje dziecko na dobrego i światłego obywatela Polskiej Rzeczypospolitej Ludowej”. „Uroczystość” kończyła się toastem fundowanym przez Koła Rodziny Milicyjnej lub inne władze. Oczywiście były zdjęcia, a w prasie codziennej i tygodniowej ukazywały się pełne zachwytu relacje nad „nową, świecką obrzędowością”. Dzieci otrzymywały prezenty, najczęściej w formie książeczek oszczędnościowych lub mieszkaniowych z niewielkim wkładem oraz zabawek (2016).

Z publikacji Łucji Marek i Moniki Bortlik-Dźwierzyńskiej wynika, że w Polsce było niewielu chętnych, więc 
władza ludowa i bezpieka pilnowała, by przede wszystkim milicjanci i żołnierze Ludowego Wojska Polskiego unikali Kościoła i byli pionierami świeckich tradycji [...] Zaczęto organizować zbiorowe uroczystości nadania imion, co z konieczności powodowało większą frekwencję. Do propagowania ,świeckiego chrztu” wykorzystywano różne okazje np. narodziny 65-tysięcznego obywatela Mysłowic czy trojaczków w Mikołowie w 1977 r., czy rocznice istnienia PRL (2015).

Piotr Osęka dodaje: ,zakazy notorycznie łamano, a «religianctwo» stanowiło jedną z głównych przyczyn kar partyjnych" (2016). Ponadto starano się zastąpić sakramenty i święta religijne poprzez wprowadzanie w ich miejsce świeckich odpowiedników, np. Pierwszą Komunię Świętą zastąpiono obrzędem pasowania na młodzika, sakrament bierzmowania - uroczystością wręczenia dowodu osobistego, Dziadek Mróz miał przejąć rolę św. Mikołaja, Gwiazdka zastępowała Boże Narodzenie, Dzień Strażaka - święto św. Floriana (Marek 2008: 7). Władza ludowa chciała towarzyszyć młodemu obywatelowi w ważnych wydarzeniach jego życia, m.in. przesyłała życzenia w pierwszą rocznicę urodzin, w dzień pójścia do szkoły czy w dzień osiągnięcia pełnoletności (Marek 2008: 7). Oprócz tego popularyzowała cywilne śluby i pogrzeby, które naśladowały, nieraz w sposób niepoważny, obrzędy kościelne. Na to wszystko zwracali uwagę biskupi polscy w „Memoriale do rządu” z 31 października 1972 r.:

Zasada wolności religijnej domaga się, aby państwo nie przejmowało na siebie funkcji kierowania aktami religijnymi, jak stwierdza soborowa Deklaracja o wolności religijnej $(\mathrm{I}, 3)$ - ale też, by nie przejmowało ono na siebie funkcji propagatora i organizatora ateizacji oraz ateistycznych form życia publicznego. Coraz częściej trzeźwiejsze głosy nawet w prasie ateistycznej zwracają uwagę, że nacisk aparatu administracji państwowej wywołuje skutek odwrotny, zwłaszcza symulanctwo i ośmieszanie władzy państwowej (Świątkiewicz).

Proces laicyzacji polskiego społeczeństwa zakończył się fiaskiem. A. Dudek, R. Gryz reasumują:

Lansowane przez środki masowego przekazu wzory nowej, świeckiej obrzędowości i obyczajowości były ignorowane przez większość Polaków. [...] uległy pewnemu nasileniu dopiero w latach siedemdziesiątych i miały związek z ogólnymi przemianami cywilizacyjnymi oraz otwarciem Polski na Zachód, nie zaś z sukcesami planowo opracowywanych w Wydziale Propagandy KC PZPR czy Urzędzie do Spaw Wyznań. Ograniczały się do kręgów rodzin wojskowych, milicyjno-esbeckich i partyjnych, w tym młodzieży z organizacji ,socjalistycznych” (2003: 276).

Należy podkreślić, że wśród krajów bloku państw socjalistycznych Polska wyróżniała się. Andrzej Nowak zwraca uwagę, że:

w innych krajach ,bloku sowieckiego” Kościół katolicki i inne istotne związki wyznaniowe zostały całkowicie rozbite lub zepchnięte do podziemia, a w Polsce społeczeństwo miało po 1950 roku wciąż silnego, legalnego sojusznika w walce o przetrwanie. 
Władzom nie udało się skutecznie podzielić Kościoła w Polsce na «postępowy» i «wsteczny», wedle polecanej przez Stalina receptury (2011: 109).

Z kolei w Czechosłowacji, a zwłaszcza na terenie Słowacji, gdzie chrześcijan było znacznie więcej, władze komunistyczne dość skutecznie walczyły z Kościołem, co przyczyniło się do tego, że w większej mierze niż w Polsce doszło do zmian narzuconych przez aparat władzy. Państwo w sposób symboliczny zawłaszczało dzieci już od narodzenia, zastąpiono sakrament chrztu powszechną uroczystością vítanía občanov, a potem w szkołach i w pionierskich oganizacjach wychowywano je zgodnie z ideologią. Za pomocą świeckich świąt budowano socjalistyczną tożsamość, kształtując nowego obywatela, pozbawionego przesądów religijnych. Chociaż w polskim społeczeństwie nie upowszechniły się uroczystości w urzędach i współcześnie nie są organizowane przez urzędy, to na Słowacji - wręcz przeciwnie - były one dość popularne, i co więcej przetrwały do dzisiaj, a nawet można mówić o pewnym ich odrodzeniu.

Obecnie na Słowacji państwo wciąż zapewnia swoim obywatelom trzy rodzaje ceremonii, tzn. dedykację (uvitanie detí do života), ślub i pogrzeb. Na uroczystość uvitanie detí do života, którą organizuje Urząd Miasta lub Urząd Gminy, wysyłane są do rodziców następujące zaproszenia: „Miasto Bańska Bystrzyca zaprasza Państwa wraz z dzieckiem, krewnymi, znajomymi i przyjaciółmi na uroczystą ceremonię uvitanie detí do života w Wielkiej Sieni Urzędu Miasta w Bańskiej Bystrzycy” lub „Urząd Gminy zaprasza Państwa wraz z dzieckiem na uroczystość uvitanie detí do života”; „Z okazji narodzin Państwa dziecka zapraszamy na ...”; ,Zapraszamy na małe przyjęcie z okazji ...”.

Bywa, że zaproszenie kierowane jest bezpośrednio do niemowląt: „Miłe dzieci urodzone w 2013 r., zapraszamy Was razem z rodzicami na uroczystość [...]”. Zdarza się, że do wyżej wymienionych tekstów dołączony jest wers: „Życie dziecka jest dla nas darem" lub wierszyk, w którym znajduje się odwołanie do sacrum: „Urocze dziecko - witaj między nami / Niech w życiu czeka Cię tylko dobry los / Niech Pan Bóg Ci błogosławi [...]”".

Szata graficzna zaproszeń i księgi pamiątkowej nie współgra ze stylem urzędowym, ponieważ zamieszczone obrazki przedstawiają niemowlę, bociana, wózek dziecięcy, bohaterów bajek. W wypadku księgi pamiątkowej z imienną listą dzieci ilustracje są często odręcznie malowane, a tekst szablonowy: „Pamiątkowy wpis z uroczystego uvitanie detí do života nowych współobywateli miasta Czadca”; „Uroczysty wpis z uroczystego uvitanie detí do života nowych współobywateli miasta Czadca”; „Uroczysty wpis z okazji uvitanie deti do života”.

Obrzęd ma również oprawę muzyczną - odtwarzane są kołysanki, piosenki przedszkolne, z bajek np. z Pszczółki Mai, Niekończącej się historii lub pieśni folklorystyczne. Czasami prezentowany jest program artystyczny, oprócz piosenek - dziecięce deklamacje i tańce ludowe. Na tę samą uroczystość zaprasza się kilka rodzin. 
Ceremonia celebrowana jest przez urzędników Urzędu Miasta. Jedna z osób dba o program artystyczny, druga odpowiedzialna jest za przebieg zgodny z protokołem, a kolejna wita gości - słowami: „Mili rodzice, dziadkowie i goście. Życzę państwu miłego południa i serdecznie witam państwa w Urzędzie Miasta Czadca na uroczystym powitaniu naszych nowo narodzonych dzieci w wielkiej rodzinie miasta Czadca". Potem przedstawia prezydenta miasta, burmistrza, wójta (w zależności od urzędu) i prosi panią z urzędu stanu cywilnego o przedstawienie panu prezydentowi miasta nowo narodzonych dzieci. Następnie urzędniczka odczytuje listę dzieci i prosi prezydenta o uroczyste przemówienie. Główny celebrant wygłasza mowę w tonie:

Szanowne mamusie, tatusiowie, szanowni goście. Dziecko jest najpiękniejszym i najdroższym darem, który napełnia i wzbogaca nasze dni [...] wspólnie z państwem, przeżywamy tę niezwykłą chwilę, dlatego pozwólcie państwo, abym z okazji tej uroczystości, kiedy witam państwa dzieci w rodzinie miasta Czadca, pogratulował ich narodzin, a naszym najmłodszym współobywatelom życzył przede wszystkim wiele miłości krewnych, bliskich, przyjaciół.

Tu następują życzenia dla dzieci i rodziców. Inny przykład mowy celebranta to: „Szanowni państwo, otwieram tę uroczystość i w imieniu urzędu serdecznie witam państwa. Mili rodzice, dziękuję, że przynieśliście swoje dzieci, aby uroczyście wprowadzić je do grona naszych obywateli” lub: „Pozwólcie mi, szanowni państwo, abym wasze dzieci, które tu przynieśliście, przyjął do grona obywateli gminy. Witajcie na świecie". Kolejny etap obrzędu to złożenie podpisów w księdze pamiątkowej i odebranie z rąk urzędnika karty pamiątkowej wraz z prezentem. Urzędniczka czuwająca nad obrzędem instruuje rodziców: „Proszę teraz miłe mamusie i tatusiów, aby ze swoim dzieckiem podeszli do stołu obrzędowego, wpisali się do księgi i odebrali od pana prezydenta pamiątkę dla dziecka".

Zazwyczaj w sali, w której odbywa się ta uroczystość, stoi drewniana kołyska, do której rodzice kładą swoje dziecko, by w tym czasie wpisać się do pamiątkowej księgi. Od urzędnika matka dziecka otrzymuje kwiatek z kopertą (z kwotą około 60 euro) i kartą pamiątkową z napisem („Miasto Czadca z radością wita naszego nowego współobywatela imię nazwisko dziecka, data urodzenia"), a niemowlę - drobną zabawkę. W mniejszych miejscowościach dodatkowo organizuje się mały poczęstunek.

Uderzający bywa zgrzyt między uroczystą oprawą obrzędu a strojem rodziców, gości. Część Słowaków ubiera się na tę uroczystość odświętnie, ale większość ubrana jest zwyczajnie, a nawet na sportowo, w bluzy dresowe. Trzeba również zaznaczyć, że na ceremonię uvítanie detí do života decydują się także te osoby, które wcześniej ochrzciły dzieci w kościele. Należy także podkreślić, że udział w uroczystości jest dobrowolny, nieprzymusowy.

W Bańskiej Bystrzycy, Koszycach na pewien czas zaprzestano organizowania tych uroczystości, jednak powrócono do tego obrzędu, również wiele urzędów miast nie zarzuciło tej tradycji. Jak podaje rzecznik prezydenta Bańskiej Bystrzycy: 
Od 2012 r. wznowiono ten obyczaj, gdyż brak tej formy powitania nowych obywateli odczuwały głównie mamy, których dzieci nie zostały ochrzczone. Największym zainteresowaniem cieszy się ze strony rodziców, którzy nie ochrzcili swoich dzieci, a więc dla których nie istnieje inna alternatywa uroczystego wprowadzenia ich dzieci do życia (www 2).

Ponadto rzecznik prezydenta poinformowała, że:

Miasto przestało organizować ceremonie głównie z powodów finansowych, ale radni przegłosowali rozporządzenie i chociaż urząd nie jest zobligowany do oferowania takiej usługi, to ze względu na długą tradycję przywrócono uvítanie detí do života (www 2).

W podobnym tonie wypowiedziała się Zuzana Mastišová z Centrum Macierzyńskiego „Mama“, która stwierdziła, że:

Matkom spodobała się ta inicjatywa urzędu: że to piękny gest i potrzebny. Miasto w ten sposób wyraziło swój stosunek do najmłodszej generacji, co spodobało się wielu rodzinom. Brakowało im takiej formy wprowadzenia do życia, chociaż w ostatnim czasie nie kładziono już na to takiego nacisku jak kiedyś (www 2).

Czym kierują się Słowacy, decydując się na udział w ceremonii, można dowiedzieć się między innymi ze słowackich stron internetowych, np.: duska88 pisze: „Mam 6-miesięczne maleństwo, którego nie ochrzciliśmy w kościele, ale ponieważ chcemy, aby miało rodziców chrzestnych, zdecydowaliśmy się na uvítanie detí do života w urzędzie" (www 4).

Wypowiedzi zamieszczone w internecie świadczą także o tym, że Słowacy nie za bardzo orientują się, jak odbywa się ceremonia: „Chiałabym się dowiedzieć, jak przebiega [uroczystość], pyta jedna z mam - jak się odpowiednio ubrać i czy wypada potem iść do restauracji?" (www 4). Internautce odpowiada halienka:

my też nie chrzciliśmy w kościele i mieliśmy tylko uvítanie detí do života. I właśnie dlatego zorganizowaliśmy prawdziwą uroczystość dla najbiższych krewnych. [...] Dla tych, którzy mieli „,chrzest klasyczny”, to nie jest już takie ważne i nie zapraszają do urzędu krewnych (www 4).

Kolejna z internautek w następujący sposób opisuje uroczystość:

Mieliśmy indywidualną uroczystość tylko dla naszego dziecka - trwała około pół godziny, był tam radny i jakieś dwie panie, grali na pianinie, śpiewali, recytowali, coś podobnego do ślubu cywilnego. Potem dostaliśmy medal i książeczkę oszczędnościową z wkładem 33 euro jako prezent od miasta, wpisaliśmy się do księgi, a w domu świętowaliśmy. Od nas też zależało, czy wybierzemy rodziców chrzestnych (tam się to inaczej nazywa, już nie wiem jak). Wybraliśmy dwie mamy chrzestne, w urzędzie nie było z tym żadnego problemu i były też wpisane w księdze pamiątkowej (www 4).

Ale można spotkać w Internecie także odmienne głosy, np.: lubicka123 pisze: 
Proszę o radę - kuzyn poprosił mnie, abym była chrzestną matką jego córki. Niedawno oznajmili mi, że chrzest będzie w ramach uvitania diet'at'a do života. [...] Prawdę mówiąc byłam rozczarowana. Chciałam zapytać, co Wasze dzieci dostały od rodziców chrzestnych podczas tej uroczystości. Kolczyki mała ma, a nie sądzę, że należy wydawać dużo pieniędzy, skoro to nie jest prawdziwy chrzest (www 4).

Podsumowując, może dziwić, że pomimo upadku komunizmu ceremonia uvítanie detí do života odbywa się nadal. Ceremonia ta funkcjonuje w społeczeństwie słowackim od lat i siłą przywiązania do tradycji utrzymuje się. Trudno jednak to zrozumieć, gdyż - jak wiadomo - Słowacy są bardzo związani ze swoją tradycją ludową, co widoczne jest np. w czasie wesel, kiedy młoda para przebiera się w strój folklorystyczny, a oczepiny są zgodne z wielowiekową tradycją. Natomiast w Polsce oczepiny zostały zastąpione przez zwyczaje, które znamy z amerykańskich filmów. Trend naśladowania zachodnich obrzędów, obcych kulturowo, stale widoczny jest w Polsce. O tym mogą świadczyć organizowane naming party (z ang. 'przyjęcie z nadaniem imienia'), odbywające się jako alternatywa dla chrztu. Jak można przeczytać na portalu onet.pl, uroczystość ma coraz więcej zwolenników:

Sama impreza niewiele różni się od popularnych chrzcin - goście również zapraszani są do domu młodych rodziców lub wynajętego lokalu, gdzie czeka na nich suto zastawiony stół, alkohol oraz tort. Różnica tkwi jedynie w braku uroczystości kościelnej naming party to impreza świecka. Podobnie w Polsce urządzane są postrzyżyny-zapleciny, zamiast komunii (www 1).

Na zakończenie trzeba stwierdzić, że na Słowacji najważniejsze wydarzenia w życiu człowieka, a więc narodziny, małżeństwo i pogrzeb mogą być celebrowane w urzędzie, a więc pieczę państwa Słowacy mogą odczuwać stale. Z kolei w Polsce uroczystości narzucane przez państwo nie stały się popularne, nie zakorzeniły się, ale współcześnie przychodzące z Zachodu nowinki budzą zainteresowanie pewnych grup.

\section{Bibliografia}

(www 1) http://kobieta.onet.pl/dziecko/naming-party-alternatywa-dla-chrzcin/vszkx [dostęp: 7.01.2016].

(www 2) http://nasabystrica.sme.sk/c/6445070/mesto-sa-vratilo-k-uvitaniam-deti-do-zivota.html\#ixzz4DEsQv2sv [dostęp: 7.01.2016].

(www 3) http://nowahistoria.interia.pl/historia-na-fotografii/swieckie-obrzedy-w-prl-zdjecie,iId,1505705,iAId,120047 [dostęp: 7.01.2016].

(www 4) https://www.modrykonik.sk/forum/rodinne-slavnosti/ako-prebieha-uvitanie-do -zivota-na-matrike/ [dostęp: 7.01.2016].

(www 5) https://www.postoj.sk/8476/ako-rodicia-obchadzali-system-ked-chcel-stat-prerobit-deti [dostęp: 7.01.2016]. 
Caillois R., 1995, Człowiek i sacrum, tłum. A. Tatarkiewicz, E. Burska, Kraków.

Dudek A., Gryz R., 2003, Komuniści i Kościół w Polsce (1945-1989), Kraków.

Kłoczkowski J., 2003, Sacrum, w: Religia. Encyklopedia PWN, red. T. Gadacz, B. Milerski, Warszawa, s. 24.

Marek Ł., 2008, Życie codzienne katolika w PRL, część 5: Przez Morze Czerwone. Kościót $w$ Polsce pod rzadami komunistów, Warszawa.

Marek Ł., Bortlik-Dźwierzyńska M., 2015, Za Marksem bez Boga. Laicyzacja życia spotecznego w Polsce w latach 1945-1989, Katowice.

Nowak A., 2011, Czas walki z Bogiem. Kościół na straży polskiej wolności, t. 4, Kraków.

Osęka P., 2016, Osęka P., 2016, Państwowy chrzest, „Newsweek Plus”, nr 5, http://www. newsweek.pl/plus/historia/peryskop/cywilny-chrzest-dla-kogo-wymyslano-swieckie -odpowiedniki-koscielnych-rytualow-,artykuly,384134,1,z.html [dostęp: 7.01.2016].

Przybylska L., 2014, Sakralizacja przestrzeni publicznych w Polsce, Gdańsk.

Semik T., 2015, Władze PRL do chrztu Polski się nie przyznaty. Polski Ludowej walka $z$ religia, „Dziennik Zachodni“ 30.05.2015, http://www.dziennikzachodni.pl/artykul/3882007,wladze-prl-do-chrztu-polski-sie-nie-przyznaly-polski-ludowej-walka-z -religia-historia-dz,id,t.html [dostęp: 7.01.2016].

Świątkiewicz W., 2016, Zamiast chrztu?, ,Idziemy” nr 2 (536), http://idziemy.pl/polityka/ zamiast-chrztu-/ [dostęp: 7.01.2016]. 
